УДК 330.59

JEL D60, I31

DOI: $10.17213 / 2312-6469-2019-4-332-338$

\title{
ОЦЕНКА КАЧЕСТВА И УРОВНЯ ЖИЗНИ НАСЕЛЕНИЯ В РЕГИОНЕ
}

\author{
(C) Н.В. Балякина 2019
}

\section{Восточно-Сибирский государственный университет технологий и управления, г. Улан-Удэ, Россия}

В данной статье были проанализированыпоказатели качества и уровня жизни населения Республики Бурятия. Рассмотрев статистические показатели величины прожиточного минимума, среднедушевых денежных доходов, среднемесячной заработной платы и структуры использования денежных доходов была представлена динамика изменения уровня жизни и дифференциация доходов населения республики.

Ключевые слова: денежные доходы, уровень потребления, качество жизни, прожиточный минимум, уровень жизни населения.

\section{EVALUATION OF QUALITY AND LIVING STANDARDS OF THE POPULATION IN THE REGION}

\author{
(C) N.V. Balyakina 2019 \\ East Siberia State University of Technology and Management, \\ Ulan-Ude, Russia
}

This article analyzes the indicators of quality and standard of living of the population of the Republic of Buryatia. On the basis of statistical indicators of the subsistence minimum, per capita income, average monthly wage and the structure of the use of cash income, the dynamics of changes in living standards and income differentiation of the population of the Republic were considered.

Key words: incomes, consumption levels, quality of life, cost of living, standard of living of population.

Кризис негативно повлиял на состояние экономики, и в первую очередь это отразилось на качественном уровне жизни населения страны, в частности, Республики Бурятия. Особенно нужно обратить внимание на один важный вопрос - изучение содержания качества и уровня жизни, основываясь на его функциях, которые определяются всей системой производственных отношений. По качеству современное состояние уровня жизни определяется его основной функцией - беспрепятственным развитием всех сторон членов общества. 
Зеркалом всей экономики страны является уровень жизни, а его составной частью - потребности. Удовлетворить их можно в процессе потребления, при помощи благ. Рассмотрим его в трех видах: применительно ко всему населению, его социальным группам и в отношении семей с разной величиной дохода. Последние две категории особенно важны для характеристики степени расслоения населения по имущественному состоянию.

Рассмотрим основные градации уровня жизни (рис. 1).

Уровень жизни определяется, прежде всего, денежными доходами населения. По данным Федеральной службы государственной статистики по Республике Бурятия, реальные располагаемые денежные доходы (доходы за вычетом обязательных платежей, скорректированные на индекс потребительских цен), по оценке, в январе 2019 года по сравнению с январем 2018 года уменьшились на 5,2\%.

По данным представленным Федеральной службой государственной статистики по Республике Бурятия: «Среднемесячная номинальная заработная плата, начисленная в январе 2019 года в организациях, не относящихся к субъектам малого предпринимательства, включая средние предприятия, микро и малые предприятия (с учетом дорасчета), по предварительной переоценке, составила 34981 руб. Наблюдаетсяснижение заработной платы на 25,7 \% по сравнению с декабрем 2018 года и увеличение на $6,9 \%$ - с январем 2018 года. Реальная заработная плата, рассчитанная с учетом индекса потребительских цен, в январе 2019 года соответствовала 73,6 \% к уровню декабря 2018 года и 100,8 \% к уровню января 2018 года».

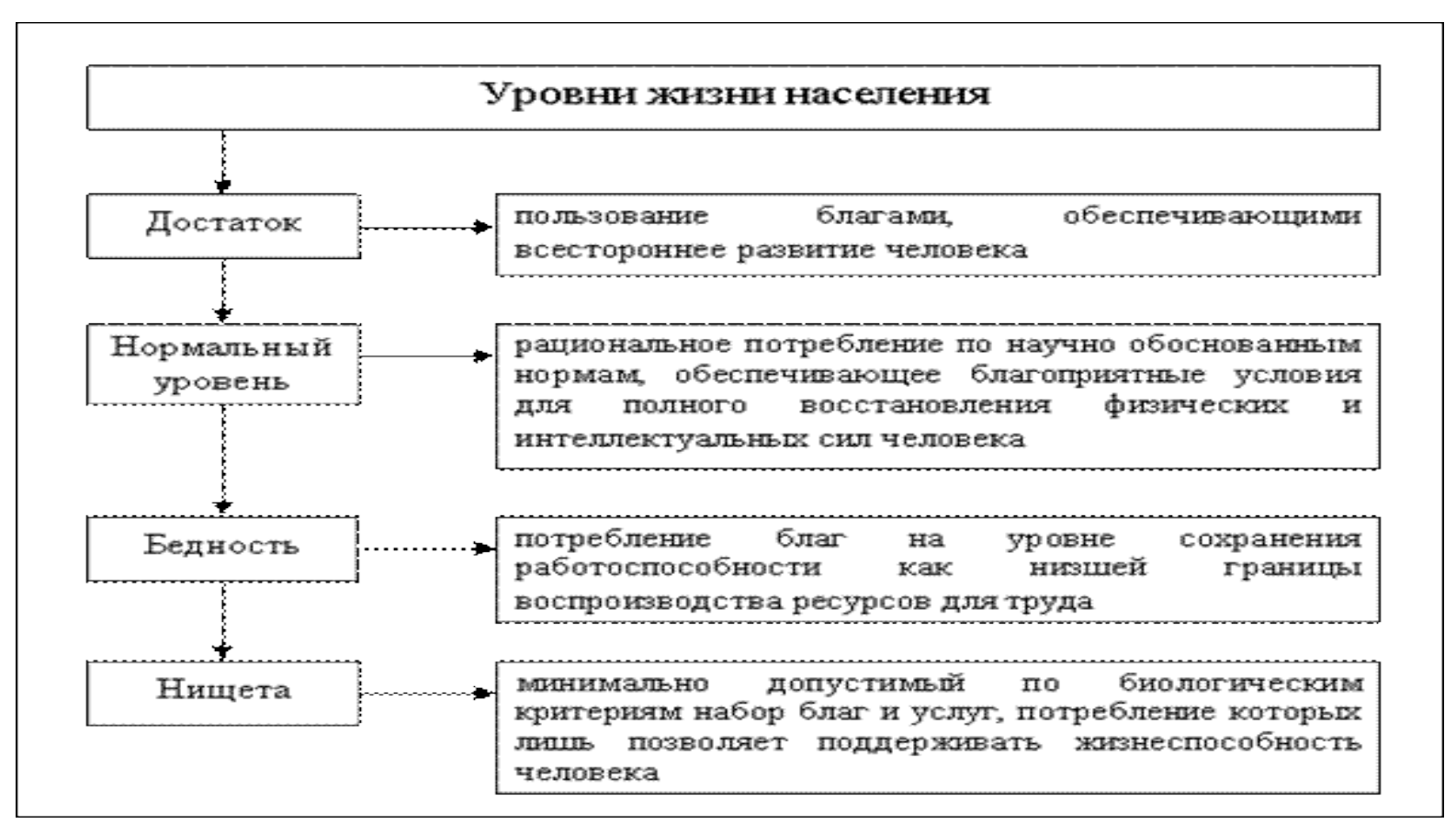

Рис. 1. Градации уровня жизни населения 
Реальные располагаемые денежные доходы населения

(в процентах к среднемесячному значению 2016 года)



Рис. 2. Реальные располагаемые денежные доходы населения

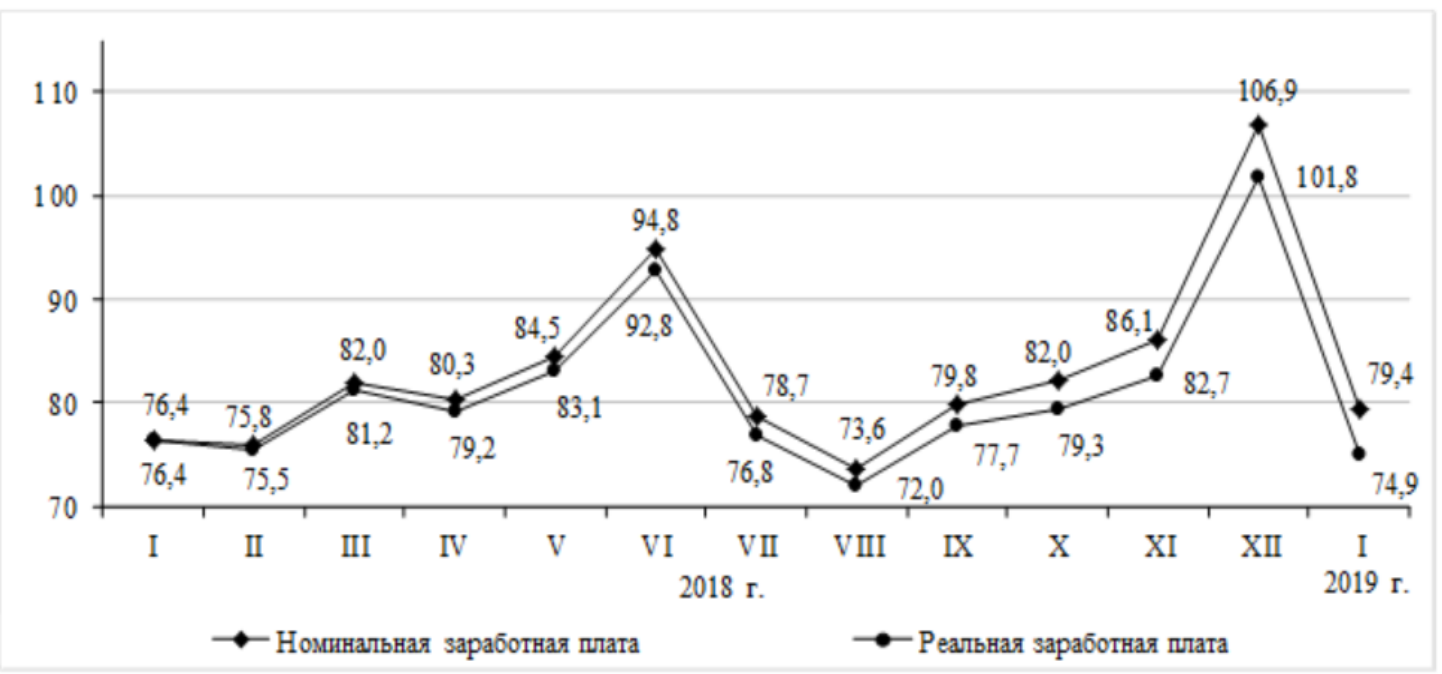

Рис. 3.Темпы роста (снижения) номинальной и реальной среднемесячной заработной платы в 2018-2019 годахк декабрю

Разделение уровней оплаты труда по видам экономической деятельности в Бурятии достаточно существенно. В январе 2019 года высокий размер начисленной заработной платы был отмечен у работников, занятых в сфере добычи полезных ископаемых, где превышен среднереспубликанский показатель в 1,8 раза, транспортировки и хранения - в 1,5 раза, социального обеспечения и государственного управления и обеспечения военной безопасности - на $13,4 \%$, финансовой и страховой деятельности - на 
31,3 \%, обеспечения электроэнергией, паром и газом, кондиционирование воздуха - на $21,5 \%$.

Самая низкая заработная плата в сравнении со среднереспубликанским значением отмечена у работников, занятых в сфере гостиниц и предприятий общепита (на 51,9 \%), торговли оптовой и розничной; ремонта автотранспортных средств и мотоциклов (на 40,4 \%), операций с недвижимым имуществом (на $37,2 \%$ ), административной деятельности и сопутствующих дополнительных услуг (на 30,0 \%), сельского, лесного хозяйства, охоты, рыболовства и рыбоводства (на 26,5 \%).

Суммарная задолженность по заработной плате по кругу наблюдаемых видов экономической деятельности по состоянию на 1 марта 2019 года равнялась 48,0 млн. рублей. Наблюдается уменьшение задолженности по заработной плате по сравнению с 1 марта 2018 года на 18,4 \%, по сравнению с 1 февраля 2019 года - увеличение на 4,6 \%. Имеется задолженность из-за несвоевременного получения денежных средств из федерального бюджета. Задолженность по заработной плате по причине отсутствия собственных средств организаций за период с 1 февраля по 1 марта 2019 года уменьшилась на 33 тыс. рублей (на $0,1 \%$ ) и составила 45,9 млн. рублей».

Рассмотрим данные Республиканского государственного учреждения «Центр социальной поддержки населения»:

«По состоянию на 28 февраля 2019 года, число получателей ежемесячного пособия на детей в возрасте от 0 до 16 (18) лет в малообеспеченных семьях составило 62,1 тыс. человек (на 9,4 \% больше, чем по состоянию на 28 февраля 2018 г.), из них 18,0 \% - одинокие матери. Пособия начислены на 144,0 тыс. детей (увеличение на 3,7 \%). С начала года начислено пособий на сумму 79,5 млн. рублей, что на 2,0 \% больше, чем за соответствующий период 2018 года. Задолженности по выплате пособий на 28 февраля 2019 годане имеется».

Рассмотрев, что такое «уровень жизни», нам необходимо раскрыть определение «качество жизни», так как оба эти понятия тесно связаны.

Итак, качество жизни включает в себя условия жизни населения, труда и занятости, быта и досуга, его здоровье, образование, природную среду обитания. Именно поэтому оно рассматривается как более сложный показатель.

Можно сказать, что этостепень удовлетворения нужд людей, по отношению к некоторым нормам, обычаям итрадициям, а также поотношению к уровню личного интереса. Иными словами, качество нашей жизни это совокупность характеристик, обозначающих материальное, социальное, физическое и культурное благополучие населения.

Рассмотрим один из основных показателей социального расслоения нашего общества - им является показатель прожиточного минимума. 
На рис. 4 представлены показатели величины прожиточного минимума в Республике Бурятия.

\section{Величина прожиточного минимума в Республике Бурятия в IV квартале 2018 года}

Во исполнение Закона Республики Бурятия от 25.12.1997 № 634-I «O прожиточном минимуме в Республике Бурятия") (по представлению Министерства экономики Республики Бурятия) Постановлением Правительства Республики Бурятия от 12.02.2019 № 50 величина прожиточного минимума за 4 квартал 2018 года установлена в размере 10395 рублей.

\begin{tabular}{|c|c|c|c|c|}
\hline & \multirow{2}{*}{$\begin{array}{c}\text { Bсе } \\
\text { население }\end{array}$} & \multicolumn{3}{|c|}{$\begin{array}{c}6 \text { том числе } \\
\text { по сочиально-демографическим } \\
\text { группам населения }\end{array}$} \\
\hline & & $\begin{array}{l}\text { трудоспо- } \\
\text { собное } \\
\text { население }\end{array}$ & пенсионеры & дети \\
\hline Величнна прожиточного минимума & 10395 & 10815 & 8263 & 10799 \\
\hline \multicolumn{5}{|l|}{ в том числе: } \\
\hline стоимость потребительской корзины & 9649 & 9625 & 8263 & 10799 \\
\hline \multicolumn{5}{|l|}{ из нее минимальный набор: } \\
\hline продуктов питания & 4846 & 4832 & 4150 & 5428 \\
\hline непродовольственных товаров & 2406 & 2401 & 2061 & 2691 \\
\hline услуг & 2397 & 2392 & 2052 & 2680 \\
\hline $\begin{array}{l}\text { расходы по обязательным платежам } \\
\text { и сборам }\end{array}$ & 746 & 1190 & $\mathrm{x}$ & $\mathrm{x}$ \\
\hline
\end{tabular}

Рис. 4. Величина прожиточного минимума в Республике Бурятия в IV квартале 2018 года

Федеральным законом РФ определяется стоимостная оценка потребительской корзины - т.е. прожиточный минимум. Сюда включены минимум услуг, продуктов питания и хоз.товаров, необходимых для обеспечения жизни, здоровья и деятельности человека. Также здесь учитываются налоги, все обязательные платежи и сборы, которые уплачивает население. Для его расчета во внимание принимаются изменения величины ВВП и государственного бюджета, индекс потребительских цен и рост доходов на душу населения.

Численность населения с денежными доходами ниже прожиточного минимума за 2017 год составила 182,1 тыс. человек $(18,5 \%$ ко всей численности населения республики). По сравнению с 2016 годом процент бедного населения вырос на 0,3 процентных пункта.

Необходимо учитывать диетологические ограничения и обеспечивать минимально необходимое количество калорий при расчете стоимостной оценки потребительской корзины. 
Существуют три основные социально-демографические группы, для которых рассчитывается показатель прожиточного минимума:

- трудоспособное население;

- пенсионеры;

- дети.

Не реже одного раза в четыре года проводится расчет оценки потребительской корзины с учетом роста потребностей и возможностей их удовлетворения.

На основании данных потребностей составляются номенклатуры показателей качества жизни. Следовательно, дальше нам нужно изучить структуру общих принципов формирования данной системы показателей.

Во многих ситуациях, в которых оценивается качество жизни, преобладает сравнительный характер, нежели абсолютный. Следовательно, главными операциями будут выбор оснований/критериев данного сравнения и определение шкал оценки.

На основании вышеперечисленных показателей можно сделать следующие выводы:

- на доходы населения влияет экономический кризис, оказывающий в большей степени своё отрицательное влияние;

- есть существенные недостатки в области оплаты труда, такие как, еѐ низкий уровень, высокая дифференциация заработной платы, обусловленная большим разбросом в системе оплаты труда, которая наблюдается на сегодняшний день во многих сферах деятельности.

В связи с этим, мы можем заявить о том, что на данный момент в Республике Бурятия происходит увеличение уровня бедности, так как начисленная заработная плата уменьшается, в связи, с чем ухудшается уровень жизни населения.

\section{Литература}

1. Зараковский Г.М. Качество жизни населения России. Психологические составляющие. - М.: Смысл, 2016. - 320 с.

2. Добренков В.И., Кравченко А.И. Методы социологического исследования. - М., 2014. $-768 \mathrm{c}$.

3. Райзберг Б.А., Лозовский Л.Ш., Стародубцева Е.Б. Современный экономический словарь. - 6-е изд., перераб. и доп. - М.: ИНФРА-М, 2011.

4. Социальное положение и уровень жизни населения России 2015 / Федеральная служба государственной статистики (Росстат). - М., 2017. - 418 с.

5. Чукреев, П. Новые методические подходы и методы регулирования уровня жизни / П. Чукреев // Проблемы нового этапа и культурного возрождения народов Бурятии (по материалам социологических исследований). - Улан-Удэ: Изд-во БНЦ СО РАН, 2011.

6. Бордоев Д.Г., Пляскина Г.Е. Анализ доходов населения Республики Бурятия в условиях экономической нестабильности // Стратегическое перепланирование и новая индустриализация: Сборник статей ежегодной научно-практической конферен- 
ции.Улан-Удэ: Издательство Восточно-Сибирского государственного университета технологий и управления, 2015.

7. Российский статистический ежегодник [Электронный pecypc]: http:// www.demoscope.ru/weekly/2018/0795/biblio05.php(дата обращения 25.04.2019).

8. Федеральная служба государственной статистики по Республике Бурятия [Электронный ресурc]: http://burstat.gks.ru/wps/wcm/connect/rosstat_ts/burstat/ru/(дата обращения 25.04.2019).

9. Федеральный закон от 24.10.1997 № 134-Ф3 (ред. от 01.04.2019) «О прожиточном минимуме в Российской Федерации».

Поступила в редакиию 06.07.2019

Балякина Наталия Владмировна - студент магистратуры ВосточноСибирского государственного университета технологий и управления, г. УланУдэ, Россия.

Balyakina Nataliya V. - Master's student at the East-Siberian State University of Technology and Management, Ulan-Ude, Russia.

Россия, 670013, г. Улан-Удэ, ул. Ключевская, 40В

40V, Kluychevskaya str., 670013, Ulan-Ude, Russia

e-mail: natalibalyakina@mail.ru 